\title{
Hypolipidemic Effects of Pea Protein Hydrolysates on Lipid Profile and Uric Acid in Cisplatin-Induced Nephropathy Rats
}

\author{
Meilinah Hidayat*, Sijani Prahastuti**, Andreas A Soemardji***, Khomaini \\ Hasan $* * * *$, Gabriella Audrey ${ }^{* * * * *}$, Janifer Gabriella $* * * * *$, Petrisia Luvina ${ }^{* * * * *}$, \\ Cicilia Liempapas $* * * * *$, Nathania C Sutanto $* * * * *$
}

*Department of Nutrition Faculty of Medicine Maranatha Christian University **Department of Biochemistry Faculty of Medicine Maranatha Christian University ***Department of Pharmacology School of Pharmacy Institut Teknologi Bandung Jl. Ganesha 10 Bandung 40132

**** Department of Biochemistry Faculty of Medicine, Ahmad Yani University Jl. Terusan Jenderal Sudirman Baros Cimahi 40525 *****Faculty of Medicine Maranatha Christian University

Jl. Prof. drg. Suria Sumantri MPH No.65 Bandung 40164 Jawa Barat Indonesia Email:mellahidayat@yahoo.com

\begin{abstract}
The usage of Cisplatin $(\mathrm{CP})$ can cause side effects such as toxicity and impaired kidney function. Poor kidney function causes dyslipidemia and hyperuricemia. Researchers in Canada state that pea protein hydrolysates can improve kidney function. The aim was to examine the hypolipidemic effect of 8 types of pea protein hydrolysate on lipid profiles and uric acid in $C P$ induced rats in purpose to find protein sources origin of Indonesia for kidney therapy. This is a true experimental study using fifty female Wistar rats divided into 10 treatment groups. We administered 8 types of pea protein hydrolysate for 30 days. On day 7 all rats (except negative control) were induced CP intraperitoneally. Study parameters was evaluated on days 12 and 30. In general, all treatments showed good hypolipidemic effects, and differed significantly from $C P$ group $(p<0.01)$. The group that showed lowest total cholesterol, LDL and triglyceride results is yellow pea protein hydrolysate Neutrase; HDL: green peas protein hydrolysate bromelain, uric acid: protein hydrolysate of pea protein isolate bromelain. As conclusion, protein hydrolysates of pea has good hypolipidemic effects on Lipid profile and Uric Acid in CP-induced nephropathy Rats.
\end{abstract}

Keywords: protein hydrolysates, green peas, neutrase, bromelain, lipid profiles, uric acid 


\title{
Efek Hipolipidemik Hidrolisat Protein Kacang Polong terhadap Profil Lipid dan Asam Urat pada Tikus dengan Kerusakan Ginjal Akibat Induksi Cisplatin
}

\author{
Meilinah Hidayat*, Sijani Prahastuti**, Andreas A Soemardji***, Khomaini \\ Hasan ****, Gabriella Audrey*****, Janifer Gabriella*****, Petrisia Luvina*****, \\ Cicilia Liempapas*****, Nathania C Sutanto***** \\ *Bagian Nutrisi Fakultas Kedokteran Universitas Kristen Maranatha, Bandung \\ **Bagian Biokimia Fakultas Kedokteran Universitas Kristen Maranatha, Bandung \\ *** Bagian Farmakologi Sekolah Farmasi Institut Teknologi Bandung \\ J1. Ganesha 10 Bandung 40132 \\ **** Bagian Biokimia Fakultas Kedokteran, Universitas Jendral Ahmad Yani \\ Jl. Terusan Jenderal Sudirman Baros Cimahi 40525 \\ ***** Fakultas Kedokteran Universitas Kristen Maranatha, Bandung \\ Jl. Prof. drg. Suria Sumantri MPH No.65 Bandung 40164 Jawa Barat Indonesia \\ Email : mellahidayat@yahoo.com
}

\begin{abstract}
Abstrak
Penggunaan Cisplatin (CP) dapat menimbulkan efek samping berupa toksisitas dan gangguan fungsi ginjal. Fungsi ginjal yang buruk menyebabkan kondisi dislipidemia dan hiperurikemia. Peneliti di Kanada menyatakan bahwa hidrolisat protein kacang polong dapat memperbaiki fungsi ginjal. Tujuan penelitian ini adalah menguji efek hipolipidemik 8 jenis protein hidrolisat kacang terhadap profil lipid (Kolesterol total, HDL, LDL, dan Trigliserida) serta asam urat sebagai akibat kerusakan ginjal pada tikus yang diinduksi $\mathrm{CP}$ dalam upaya menemukan kacang polong asal Indonesia untuk terapi perbaikan fungsi ginjal. Penelitian dilakukan menggunakan 50 ekor tikus Wistar betina yang dibagi menjadi 10 kelompok perlakuan dengan pemberian 8 jenis hidrolisat protein kacang selama 30 hari. Pada hari ke 7 semua tikus (kecuali kontrol negatif) diinduksi CP secara intraperitoneal. Pemeriksaan parameter penelitian dilakukan pada hari ke 12 dan 30. Secara umum semua kelompok hidrolisat protein kacang menunjukkan efek hipolipidemik yang baik, dan berbeda sangat signifikan dengan kelompok $\mathrm{CP}(\mathrm{p}<0,01)$. Kelompok yang menunjukkan penurunan kadar kolesterol total, LDL dan trigliserida paling baik adalah hidrolisat protein polong kuning Neutrase (HPPKN); HDL: hidrolisat protein polong hijau bromelain (HPPHB), asam urat: hidrolisat protein Pea protein isolate bromelain (HPPIB). Simpulan, hidrolisat protein kacang polong Indonesia dan Kanada menunjukkan efek hipolipidemik sebaik terhadap profil lipid dan Asam Urat.
\end{abstract}

Kata kunci: hidrolisat protein, kacang polong hijau, neutrase, bromelain, profil lipid, asam urat 


\section{Pendahuluan}

Kerusakan ginjal telah menjadi masalah kesehatan global dengan prevalensi dan insidensi gagal ginjal yang meningkat, prognosis yang buruk, serta anggaran biaya yang tinggi. Di Indonesia, anggaran perawatan penyakit ginjal menempati peringkat kedua pembiayaan terbesar dari BPJS kesehatan setelah penyakit jantung. ${ }^{1}$ Pada tahun 2010, penyakit ginjal kronik (PGK) menempati peringkat ke-18 penyebab kematian di dunia. ${ }^{2}$ Kerusakan ginjal akut yang tidak ditangani dengan baik selama 7 hari, terutama pada stadium 3-5 sering menyebabkan komplikasi berupa PGK. Penggunaan terapi Cisplatin dapat menyebabkan efek samping berupa toksisitas, gangguan fungsi dan kerusakan ginjal. Tingkat keparahan toksisitas jaringan ginjal bergantung dari konsentrasi $\mathrm{CP}$. Infus larutan dengan konsentrasi $\mathrm{CP}$ lebih dari $0,5 \mathrm{mg} / \mathrm{mL}$ dapat menyebabkan selulitis jaringan, fibrosis, dan nekrosis. ${ }^{3,4}$

PGK terutama yang berhubungan dengan proteinuria, sering disertai dengan abnormalitas transpor lipoprotein serta gangguan metabolisme asam urat. Dislipidemia yang terjadi ditandai dengan peningkatan kadar trigliserida serum dan VLDL (very low density lipoprotein), apolipoprotein B dan pre- $\beta$ lipoprotein, serta penurunan kadar HDL (high density lipoprotein) dan apoA. Pada pasien proteinuria kadar kolesterol total dapat meningkat sangat tinggi. ${ }^{5}$ Hal ini berhubungan dengan permeabilitas glomerulus yang abnormal terhadap protein plasma dan penurunan tekanan onkotik serum. ${ }^{6}$ Pada PGK, sel dan jaringan ginjal mengalami kerusakan yang parah dan menetap sehingga metabolisme asam urat juga terganggu. Hiperurisemia terjadi akibat kondisi ekskresi asam urat menurun (disebabkan gangguan kemampuan filtrasi glomerulus, sekresi tubular, dan reabsorpsi tubular), kondisi produksi asam urat meningkat karena diet tinggi purin atau kombinasi dari kedua kondisi tersebut. ${ }^{7}$

Hasil penelitian di Kanada menyatakan bahwa hidrolisat protein kacang polong merupakan sumber makanan yang dapat menurunkan tekanan darah tinggi dan mencegah perburukan fungsi ginjal. Pada penelitian tersebut, tikus yang ginjalnya dirusak mengalami perbaikan setelah pemberian protein hidrolisat kacang polong selama 8 minggu berupa penurunan tekanan darah sebesar $20 \%$ dibandingkan dengan tikus yang diberikan diet normal. Dihipotesiskan bahwa mekanisme protein kacang polong dalam menurunkan tekanan darah dan memperbaiki fungsi ginjal adalah dengan cara stimulasi produksi siklooksigenase 1 (COX-1), yaitu suatu protein yang dapat meningkatkan fungsi ginjal. ${ }^{8,9}$

Di Indonesia kacang polong kuning seperti yang banyak ditanam di Kanada masih belum banyak. Akan tetapi terdapat banyak jenis kacang polong lain di Indonesia. Dalam penelitian ini, telah dianalisis efek dari delapan jenis hidrolisat protein yang diperoleh dari 4 jenis kacang yang dihidrolisis menggunakan 2 jenis enzim, Neutrase dan bromelain (enzim 
pemecah protein yang diperoleh dari nanas) terhadap fungsi ginjal tikus Wistar yang diinduksi oleh Cisplatin (CP). Hasil menunjukkan bahwa pada hari ke 12 semua kelompok perlakuan (kecuali kontrol negatif) menunjukkan peningkatan kadar Ureum dan kreatinin ( $p<0,01) .{ }^{10,11}$ Hal ini menunjukkan bahwa pada tikus percobaan telah terjadi kerusakan ginjal yang parah.

Tujuan penelitian ini adalah menguji efek hipolipidemik 8 jenis protein hidrolisat terhadap profil lipid (Kolesterol total, HDL, LDL, LDL dan Trigliserida) serta asam urat sebagai komplikasi akibat kerusakan ginjal pada tikus yang diinduksi CP dalam upaya menemukan terapi sumber protein asal Indonesia untuk perbaikan fungsi ginjal.

\section{Metode}

Penelitian ini merupakan penelitian eksperimental sungguhan dengan metode Rancang Acak Lengkap (RAL) bersifat komparatif. Bahan penelitian yang digunakan adalah empat jenis sumber kacang yaitu: biji kering kacang polong Kuning Kanada (Pisum sativum) diperoleh dari toko di kota Toronto, Kanada; biji kering kacang gude (Cajanus cajan) dari desa Cijengkol, Punclut, Bandung, Jawa Barat Indonesia; biji kering kacang polong hijau (Pisum sativum L) dari Maica Leaf, Perkebunan Magelang, Jawa Timur Indonesia; tepung isolat protein kacang polong (Pisum sativum) dibeli dari canadianprotein.com (Produk \#: EMW lot 161216100PEAP). Protein yang mengandung enzim neutrase dibeli dari Brenntag Connecting Chemistry (Asia Pacific). Enzim bromelain diperoleh dari jus nanas segar (Ananas sativus) dari daerah Subang. CP untuk injeksi / i.p dibeli dari apotik setempat, produksi Dankos Farma, Jakarta, Indonesia.

Subjek Penelitian adalah 50 ekor tikus Wistar betina (berusia 5-6 minggu), dengan berat 148-190 g, nullipara dan tidak hamil berasal dari Sekolah Ilmu dan Teknologi Hayati (Sekolah Ilmu dan Teknologi Hayati), Institut Teknologi Bandung (ITB), Indonesia.

Metode Pembuatan Hidrolisat Protein disiapkan menggunakan metode sebelumnya. ${ }^{8}$ Empat jenis kacang yang telah dihaluskan disaring melalui ayakan MESH no 120. Masingmasing ditimbang sebanyak $50 \mathrm{~g}$ kemudian dilarutkan dalam $200 \mathrm{~mL}$ air. Neutrase atau bromelain ditambahkan ke setiap larutan, kemudian diaduk pada suhu kamar dan dibiarkan sekitar 72 jam. Setelah inkubasi, setiap larutan dipindahkan ke tabung dan disentrifugasi pada $6.000 \mathrm{~g}$ selama 10 menit. Supernatan disaring menggunakan kertas saring. Kandungan protein dalam masing2 hidrolisat protein kacang diukur tiap mLnya. Kandungan protein dihitung dengan cara membagi absorbansi sampel hidrolisat pada diencerkan 50x (0,02 sampel + 0,98 aquadest) pada panjang gelombang A280 dengan persamaan BSA. Hasilnya adalah: HPPKN = 40,84mg / mL; HPPKB = 27,61 mg / mL; HPKGN = 32,93 mg / mL; HPKGB = 22,30 mg / 
$\mathrm{mL} ; \mathrm{HPPHN}=56,69 \mathrm{mg} / \mathrm{mL} ; \mathrm{HPPHB}=47,31 \mathrm{mg} / \mathrm{mL} ; \mathrm{HPPPIN}=61,59 \mathrm{mg} / \mathrm{mL} ; \mathrm{HPPPIB}$ $=37,56 \mathrm{mg} / \mathrm{mL}^{11}$

\section{Percobaan in vivo pada Tikus Wistar}

Sebanyak 50 tikus Wistar betina dibagi menjadi sepuluh kelompok dengan perlakuan berbeda. Percobaan ini telah mendapat persetujuan dari Komisi Etik Universitas Kristen Maranatha (084 / KEP FK UKM-RSI / III / 2017). Setiap tikus dari kelompok 1-8 terus diberikan hidrolisat protein kacang selama 30 hari dengan dosis $100 \mathrm{mg} / \mathrm{kgBB} /$ hari sebagai berikut:

1. Hidrolisat protein kacang polong kuning Kanada, dihidrolisis oleh Neutrase (HPPKN)

2. Hidrolisat protein kacang polong kuning Kanada, dihidrolisis oleh bromelain (HPPKB)

3. Hidrolisat protein kacang gude, dihidrolisis dengan Neutrase (HPKGN)

4. Hidrolisat protein kacang gude, dihidrolisis oleh bromelain (HPKGB)

5. Hidrolisat protein kacang polong hijau, dihidrolisis oleh Neutrase (HPPHN)

6. Hidrolisat protein kacang polong hijau, dihidrolisis oleh bromelain (HPPHB)

7. Hidrolisat protein Isolat protein kacang polong, dihidrolisis dengan Neutrase (HPPPIN)

8. Hidrolisat protein Isolat protein kacang polong, dihidrolisis oleh bromelain (HPPPIB)

9. Kontrol negatif: tikus tidak diberi perlakuan $(\mathrm{KN})$

10. Kontrol CP: tikus hanya diberi CP $10 \mathrm{mg} / \mathrm{kgBB}$ (satu kali) (KP)

Setelah semua tikus diadaptasi selama 7 hari, pada hari ke tujuh, tikus-tikus dikelompokkan secara acak menjadi 10 kelompok dan setiap tikus disuntik dengan CP intraperitoneal $10 \mathrm{mg} / \mathrm{kgBB}$ (satu kali), kecuali tikus kontrol negatif (kelompok 9). Lima hari kemudian, pada hari ke 12 semua tikus diambil sampel darah dari vena ekor, untuk diperiksa kadar urea dan kreatinin serum untuk memastikan telah terjadi gangguan dan kerusakan ginjal. Kadar lipid serum, yaitu kolesterol total, HDL, LDL, dan trigliserida; dan asam urat diperiksa pada hari ke 12 dan 30.

\section{Pemeriksaan Kadar Lipid Tikus}

Sampel darah tikus diambil dari vena ekor, disentrifus selama 10 menit 600rpm, kemudian serum yang didapat diperiksa kadar ureum, kreatinin, kolesterol total, HDL, LDL dan asam urat menggunakan alat COBAS ROCHE 311; dilakukan 2 kali yaitu pada hari ke 12 dan ke 30 dengan prinsip spektrofotometri, menggunakan enzim Cholesterol-oxidasephenol aminophenazone (CHOD-PAP); sedangkan kadar Trigliserida diperiksa menggunakan enzim Glycerol-3-phosphate oxidase-phenol aminophenazone (GPO-PAP). 


\section{Analisis Data}

Nilai data disajikan sebagai rata-rata \pm SD. Setelah dilakukan uji Levenne untuk homogenitas dan Kolmogorov-Smirnov untuk uji normalitas, data hasil hari ke 12 dan hari ke 30 dianalisis dengan ANAVA diikuti oleh uji lanjut post Hoc LSD test. Perbandingan hasil data antara hari ke 12 dengan hari ke 30 dianalisis menggunakan uji t berpasangan. Perbedaan dianggap signifikan secara statistik jika $\mathrm{p}<0,05$ dan sangat signifikan jika $\mathrm{p}<0,01$.

\section{Hasil}

Pada hari ke-12 hasil pemeriksaan kadar ureum dan kreatinin kelompok CP dibandingkan dengan kelompok kontrol negatif didapatkan perbedaan yang sangat bermakna $(\mathrm{p}<0,01)$. Hal ini menunjukkan bahwa pemberian induksi $\mathrm{CP}$ terbukti merusak ginjal. ${ }^{11}$

\section{Hasil Pemeriksaan Kadar Kolesterol Total}

Hasil Rerata Kadar Kolesterol Total Serum Tikus yang diinduksi CP pada Hari ke-12 dan ke-30 dapat dilihat pada gambar 1 .

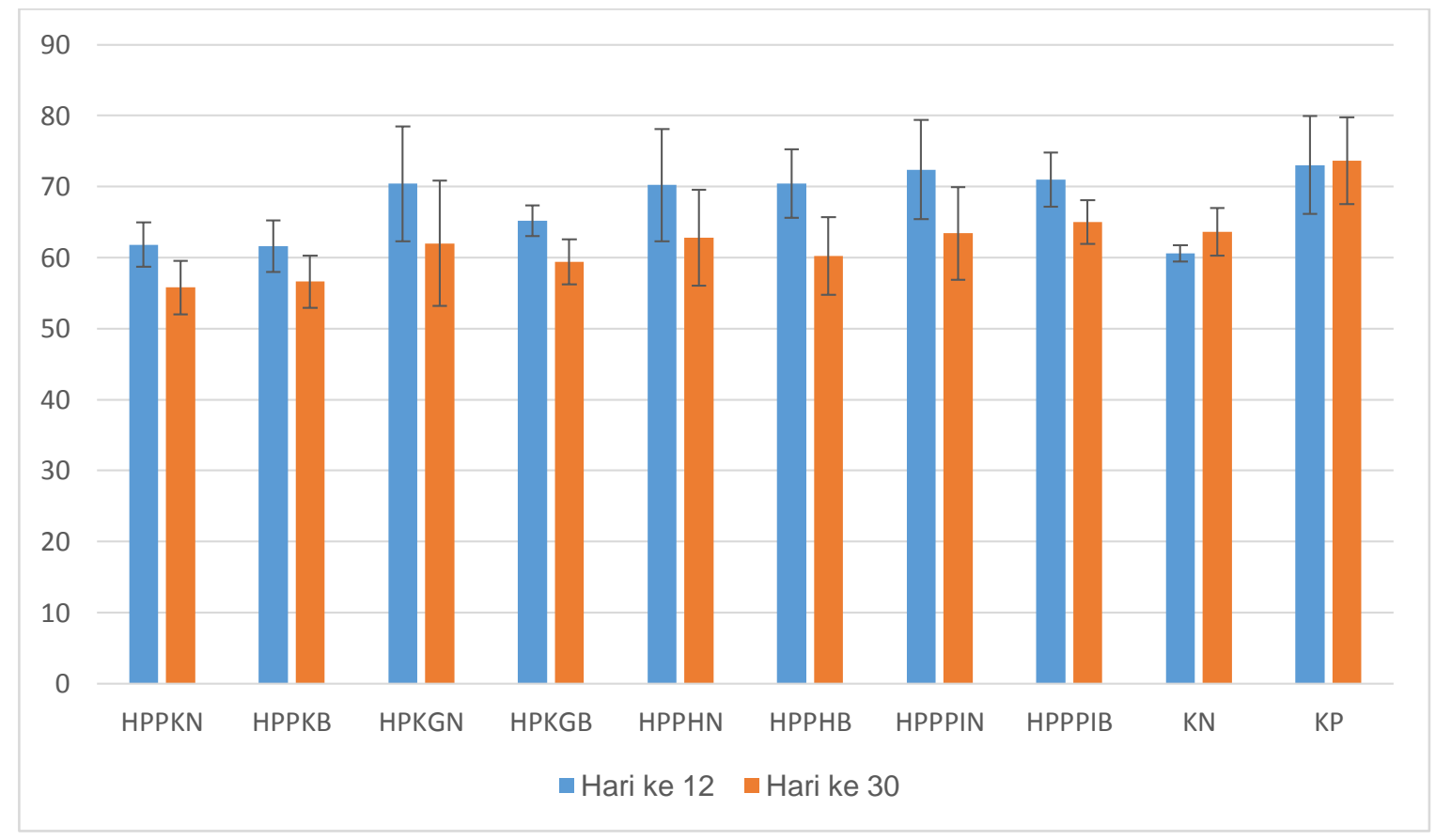

Gambar 1 Hasil Analisis Hasil Rerata Kadar Kolesterol Total

Keterangan: Harga Normal Kolesterol Total Tikus : 20 - 92 mg/dL ${ }^{12}$ 
Hasil rerata kadar kolesterol total serum tikus hari ke 12 didapatkan kelompok yang paling rendah kadar kolesterolnya adalah HPPKB dan pada hari ke-30 kelompok yang paling rendah adalah kelompok HPPKN. Hasil uji normalitas data menggunakan metode KolmogrovSmirnov didapatkan peningkatan data kolesterol total serum yang berdistribusi normal $(p>0,05)$ dan juga data telah dipastikan homogen dengan uji Levenne. Hasil uji statistik ANAVA kelompok perlakuan hari ke-12 dan hari ke-30 masing-masing menunjukkan perbedaan yang sangat bermakna antar kelompok $(\mathrm{p}<0,01)$. Hasil pengukuran kolesterol total serum hari ke-12 antara kelompok KP dibandingkan dengan kelompok KN didapatkan perbedaan yang sangat bermakna $(p<0,01)$. Didukung data hasil pemeriksaan kadar ureum dan kreatinin, diasumsikan bahwa induksi CP terbukti merusak ginjal yang selanjutnya meningkatkan kadar kolesterol total serum tikus Wistar. Hasil kelompok HPPKN dan HPPKB yang dibandingkan dengan kontrol CP menunjukkan perbedaan yang sangat bermakna $(\mathrm{p}<0,01)$ sedangkan kelompok HPKGN, HPPHN, HPPHB, PHKPIN, PHKPIB dibandingkan dengan kelompok kontrol CP menunjukkan perbedaan yang tidak bermakna $(p>0,05)$.

Hal ini menunjukkan bahwa pemberian hidrolisat HPPKN \& HPPKB berefek menjaga kadar kolesterol total serum tikus Wistar yang diinduksi CP. Disimpulkan bahwa pemberian hidrolisat protein kacang polong kuning, dengan enzim Neutrase dan bromelain pada hari ke-12 berefek paling baik dalam menurunkan kadar kolesterol total serum tikus Wistar yang diinduksi $\mathrm{CP}$.

Pada hari ke-30 perbandingan kelompok CP dengan kelompok kontrol negatif menunjukkan perbedaan yang sangat bermakna $(\mathrm{p}<0,01)$. Semua kelompok perlakuan yang diberi 8 jenis hidrolisat protein dibandingkan kelompok CP menunjukkan perbedaan yang sangat bermakna $(\mathrm{p}<0,01)$. Disimpulkan bahwa pemberian hidrolisat protein kacang polong kuning, kacang gude, kacang polong hijau, kacang polong isolat dengan enzim Neutrase maupun bromelain mampu menurunkan kadar kolesterol total serum pada tikus Wistar yang diinduksi CP.

\section{Hasil Pemeriksaan Kadar HDL}

Hasil pemeriksaan kadar HDL serum tikus yang diinduksi CP hari ke 12 dan 30 dapat dilihat pada Gambar 2. 


\section{Research Article}

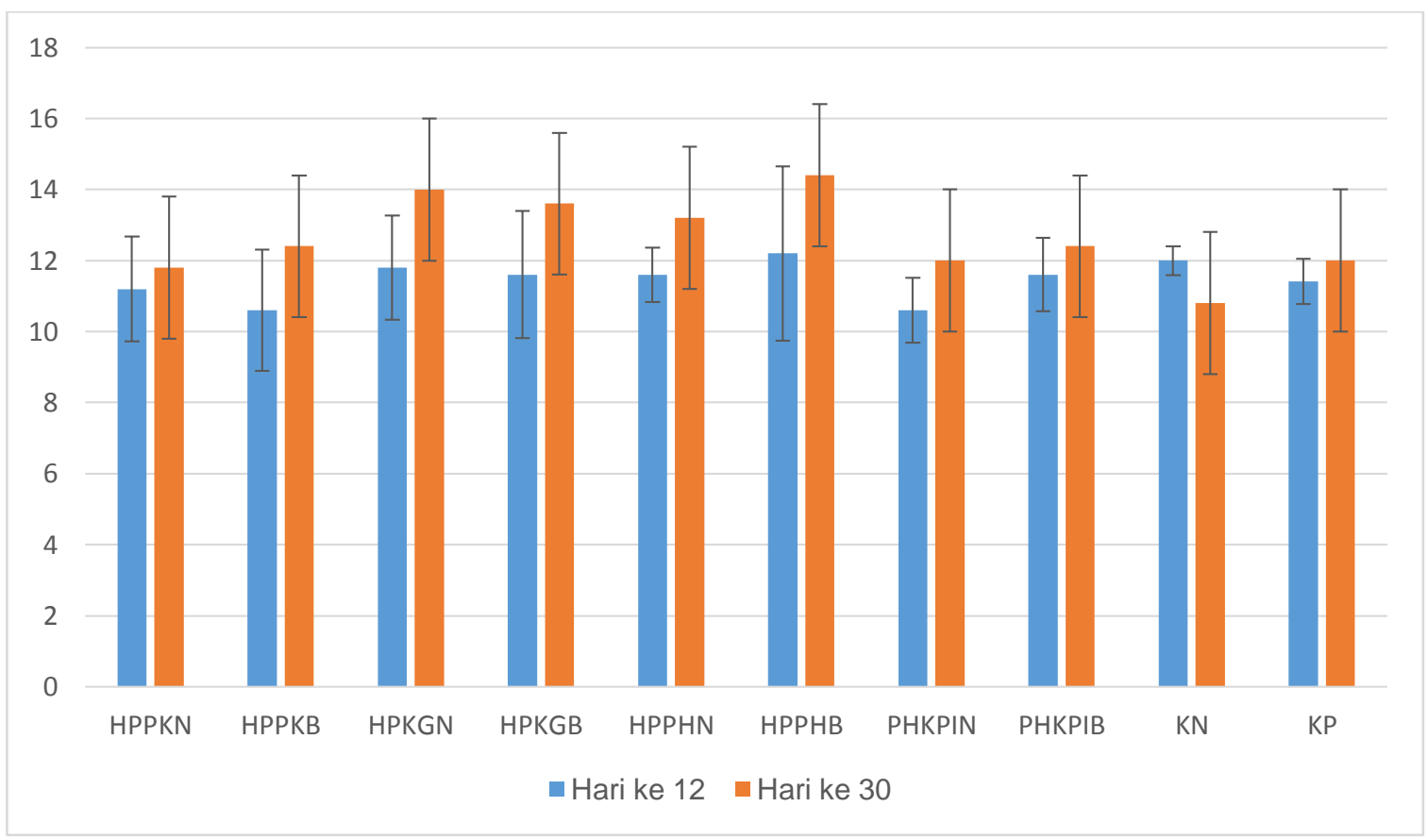

Gambar 2. Hasil Analisis Hasil Rerata HDL

Keterangan: Harga Normal HDL Tikus : $2-27 \mathrm{mg} / \mathrm{dL}^{12}$

Dari gambar 2 terlihat bahwa kelompok HPPHB merupakan kelompok yang menunjukkan hasil paling baik dalam meningkatkan kadar HDL. Rerata kadar HDL serum hari ke-12 adalah 12, 20 sedangkan hari ke-30 adalah 14,40.

Dari hasil uji statistik ANAVA satu arah, baik hari ke 12 maupun hari ke 30 didapatkan hasil yang sangat bermakna $(\mathrm{p}<0,01)$ antar kelompok. Uji statistik lebih lanjut dengan uji beda rata-rata metode LSD menunjukkan kelompok mana saja yang menunjukkan perbedaan. Hasil analisis rerata kadar HDL kelompok KN menunjukkan perbedaan yang sangat bermakna dengan KP $(\mathrm{p}<0,01)$.

Kelompok KP menunjukkan perbedaan yang sangat bermakna dengan HPKGN, HPKGB, HPPHN, dan HPPHB $(\mathrm{p}<0,01)$ namun berbeda bermakna $(\mathrm{p}<0,05)$ dengan kelompok HPPKN, HPPHB, PHKPIN, dan PHKPIB, berarti dengan pemberian kacang gude dan kacang polong hijau menggunakan enzim Neutrase dan bromelain terbukti dapat meningkatkan kadar HDL serum lebih baik dibandingkan kacang polong kuning dan protein isolat kacang polong menggunakan enzim Neutrase dan bromelain. 


\section{Hasil Pemeriksaan Kadar LDL}

Hasil pemeriksaan kadar LDL serum tikus yang diinduksi CP hari ke 12 dan 30 dapat dilihat pada Gambar 3.

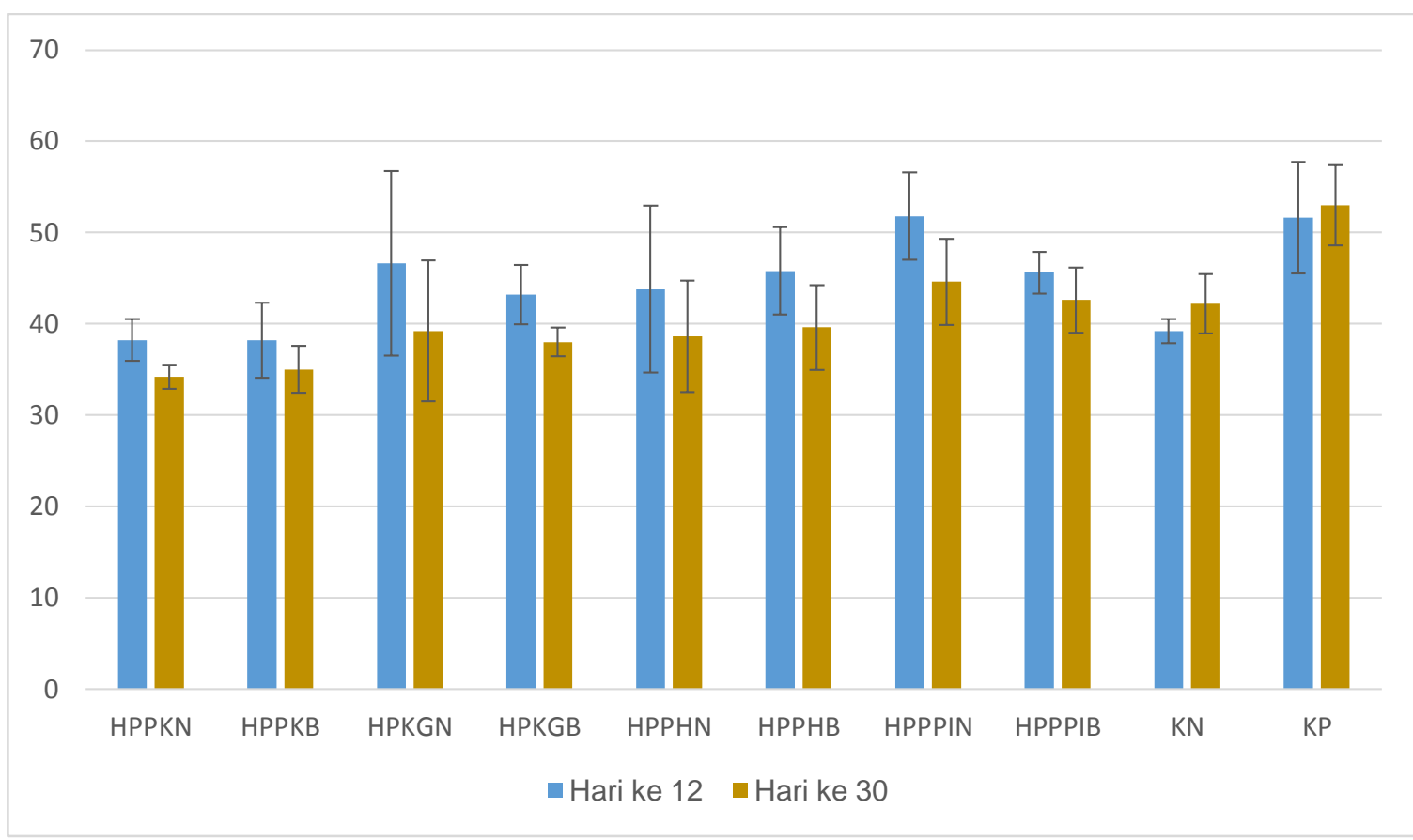

Gambar 3. Hasil Analisis Hasil Rerata Kadar LDL

Keterangan: Harga Normal LDL Tikus : $35-50 \mathrm{mg} / \mathrm{dL}^{13}$

Hasil uji statistik ANAVA terhadap rerata kadar LDL menunjukkan perbedaan yang bermakna antara kelompok perlakuan, baik pada hari ke-12 dan hari ke-30 ( $\mathrm{p}<0,05)$. Uji statistik dilanjutkan dengan uji lanjut beda rata-rata LSD. Berdasarkan gambar 3, pada hari ke12, terlihat bahwa antara kelompok KP dibandingkan kelompok $\mathrm{KN}$ menunjukkan perbedaan yang sangat bermakna $(p<0,01)$. Hasil pengukuran LDL kelompok HPPKN dan HPPKB dibandingkan dengan kelompok $\mathrm{CP}$ menunjukkan perbedaan yang sangat bermakna $(p<0,01)$. Hasil pengukuran kelompok HPKGN, HPKGB, HPPHN, HPPHB, HPPPIN, HPPPIB menunjukkan perbedaan yang bermakna $(\mathrm{p}<0,05)$ jika dibandingkan dengan kontrol $\mathrm{CP}$.

Pada hari ke-30, tikus kelompok KP dibandingkan dengan kelompok KN menunjukkan perbedaan yang sangat bermakna $(\mathrm{p}<0,01)$. Hal ini menunjukkan induksi $\mathrm{CP}$ memang merusak fungsi ginjal sehingga meningkatkan kadar LDL tikus Wistar. Hasil pemeriksaan LDL serum tikus Wistar yang diberi HPPKN, HPPKB, HPKGN, HPKGB, HPPHN, HPPHB menunjukkan perbedaan yang sangat bermakna bila dibandingkan dengan kontrol CP $(\mathrm{p}<0,01)$. Kadar LDL serum tikus Wistar yang diberikan HPPPIN dan HPPPIB menunjukkan perbedaan yang bermakna bila dibandingkan dengan kontrol $\mathrm{CP}(\mathrm{p}<0,05)$. Hal ini menunjukkan bahwa semua 


\section{Research Article}

pemberian hidrolisat protein memiliki efek menurunkan kadar LDL serum tikus Wistar yang diinduksi CP.

Rerata kadar LDL serum tikus Wistar betina pada hari ke-12 dan hari ke-30 yang paling rendah didapatkan pada kelompok HPPKN meskipun secara statistik tidak berbeda bermakna dengan kelompok HPPKB.

\section{Pemeriksaan Kadar Trigliserida}

Hasil pemeriksaan kadar Trigliserida serum tikus yang diinduksi CP hari ke 12 dan 30 dapat dilihat pada Gambar 4.

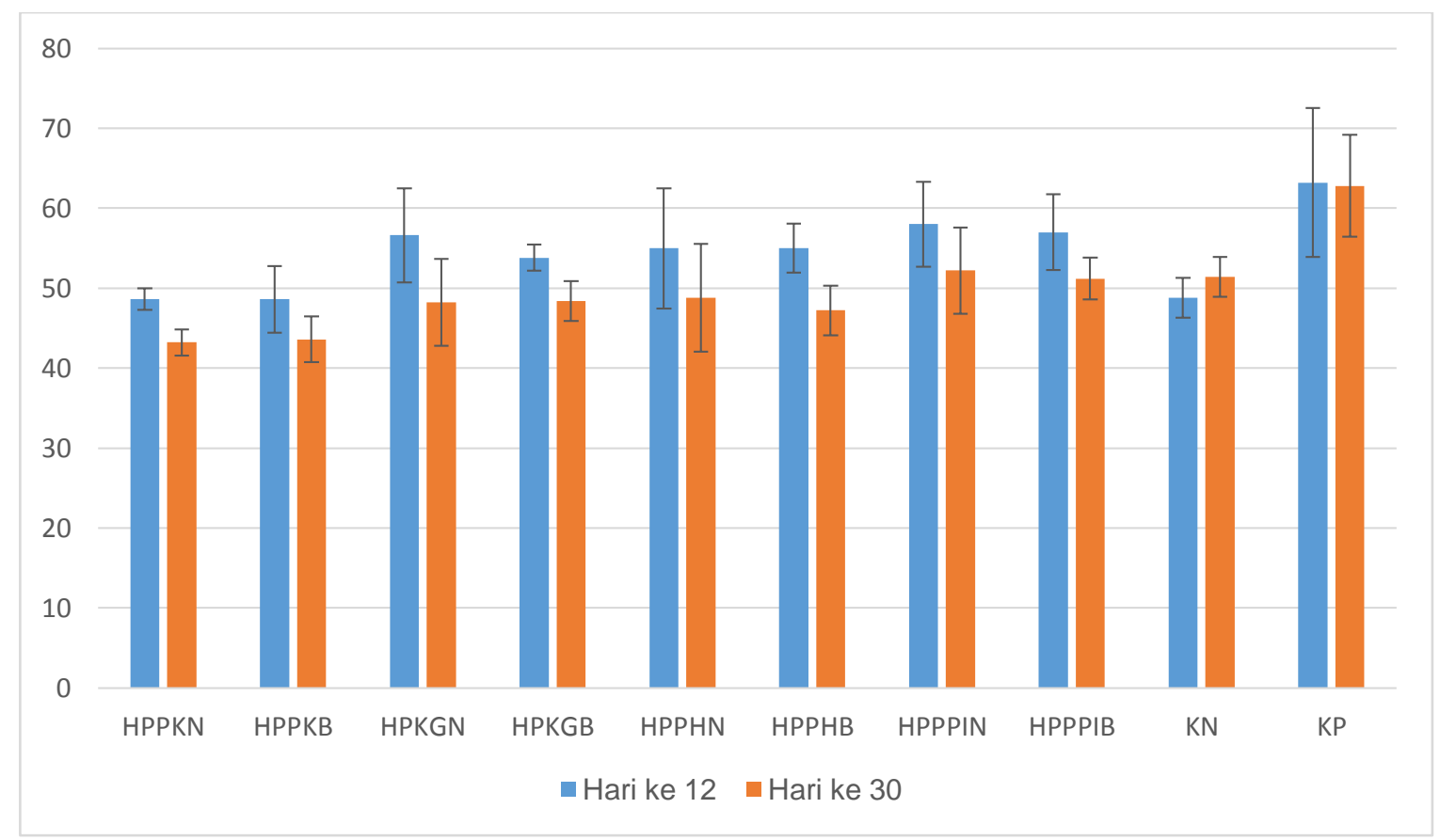

Gambar 4. Hasil Analisis Hasil Rerata Kadar Trigliserida

Keterangan: Harga Normal Trigliserida Tikus: $27-108 \mathrm{mg} / \mathrm{dL}^{11}$

Hasil uji statistik ANAVA kadar rerata menunjukkan perbedaan yang sangat bermakna antara kelompok perlakuan pada hari ke-12 dan hari ke-30 ( $\mathrm{p}<0,01)$. Uji statistik dilanjutkan dengan uji beda rata-rata LSD untuk menunjukkan kelompok yang menunjukkan perbedaan. Dari gambar 4 terlihat bahwa pada hari ke-12, kelompok KP dibandingkan KN menunjukkan perbedaan yang sangat bermakna $(\mathrm{p}<0,01)$. Induksi CP terbukti menyebabkan peningkatan kadar trigliserida tikus Wistar. Kelompok yang diberikan HPPKN dan HPPKB dibandingkan dengan kelompok KP menunjukkan perbedaan yang sangat bermakna $(p<0,01)$. Pemberian 
HPKGN, HPKGB, HPPHN, HPPHB, HPPPIN, dan HPPPIB menurunkan kadar trigliserida berbeda bermakna $(\mathrm{p}<0,05)$ jika dibandingkan dengan $\mathrm{KN}$. Pemberian hidrolisat protein pada hari ke-12 belum menunjukkan efek yang jelas terhadap kadar trigliserida serum tikus Wistar yang diinduksi CP.

Pada hari ke-30, kelompok KP dibandingkan dengan kelompok KN menunjukkan perbedaan yang sangat bermakna $(p<0,01)$. Kelompok yang diberikan HPPKN, HPPKB, HPKGN, HPKGB, HPPHN, HPPHB, HPPPIN, dan HPPPIB menunjukkan perbedaan yang sangat bermakna bila dibandingkan dengan $\mathrm{KP}(\mathrm{p}<0,01)$. Hal ini menunjukkan bahwa semua hidrolisat protein kacang polong dan kacang gude mampu menurunkan kadar trigliserida serum tikus Wistar yang diinduksi CP. Rerata kadar trigliserida serum tikus Wistar hari ke-30 yang paling rendah pada kelompok HPPKN walaupun hasil analisis statistika menunjukkan tidak berbeda bermakna dengan kelompok hidrolisat protein yang lain.

Pada uji t berpasangan kelompok KP antara hari ke 12 dan hari 30 tidak menunjukkan penurunan kadar trigliserida serum yang bermakna ( $p>0,05)$, demikian juga kelompok KN. Pemberian semua jenis hidrolisat protein kacang polong dan kacang gude menunjukkan penurunan kadar trigliserida serum yang bermakna $(\mathrm{p}<0,05)$. Kelompok yang diberikan HPPHB menunjukkan penurunan yang paling bermakna $(\mathrm{p}=0,000)$.

\section{Pemeriksaan Kadar Asam Urat}

Hasil pemeriksaan rerata kadar asam urat dapat dilihat pada Gambar 5.

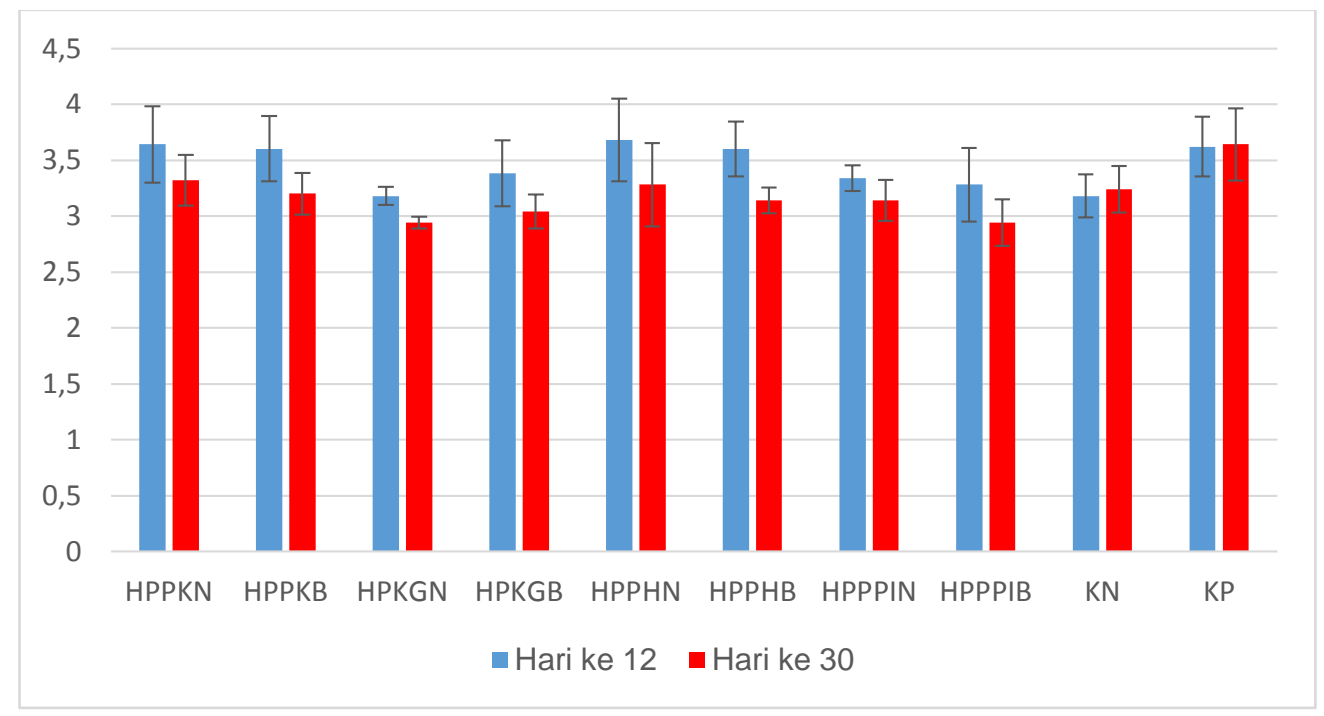

Gambar 5. Hasil Analisis Hasil Rerata Kadar Asam Urat

Keterangan: Harga Normal Asam Urat Tikus: 0,8 - 4,4 mg/dL. ${ }^{12}$ 
Hasil uji statistik ANAVA satu arah terhadap rerata kadar asam urat hari ke-12 dan -30 masing-masing menunjukkan hasil yang sangat bermakna $(\mathrm{p}<0,01)$. Uji statistik dilanjutkan dengan uji beda rata-rata Post Hoc LSD untuk menunjukkan kelompok yang menunjukkan perbedaan.

Pemberian semua jenis hidrolisat protein kacang polong dan kacang gude menyebabkan penurunan kadar asam urat pada hari ke-30. Kelompok HPPKB, HPKGN, HPKGB, HPPHB, HPPPIN, dan HPPPIB dibandingkan dengan kelompok KP menunjukkan perbedaan yang sangat bermakna $(p<0,01)$. Kelompok HPPKN dan HPPHN dibandingkan dengan KP menunjukkan perbedaan yang bermakna $(\mathrm{p}<0,05)$.

Pada uji t berpasangan, kelompok PHYPN, PHYPB, PHGBN, PHGBB, PHGPN, PHGPB antara kadar asam urat serum antara hari ke-12 dan hari ke-30 menunjukkan perbedaan yang sangat bermakna $(\mathrm{p}<0,01)$, sedangkan kelompok HPPPIN dan HPPPIB menunjukkan hasil yang bermakna $(\mathrm{p}<0,05)$ (Gambar 5). Hal ini berarti pemberian semua jenis hidrolisat protein kacang dalam penelitian ini mempunyai efek menurunkan kadar asam urat serum tikus Wistar yang diinduksi CP.

\section{Diskusi}

Secara umum semua kelompok hidrolisat protein kacang menunjukkan efek hipolipidemik yang baik, dan berbeda sangat signifikan dengan $\mathrm{KP}(\mathrm{p}<0,01)$. Akan tetapi kelompok yang menunjukkan hasil kolesterol total paling baik adalah HPPKN, kelompok yang menunjukkan hasil HDL paling baik: HPPHB, kelompok yang menunjukkan hasil LDL paling baik: HPPKN dan kelompok yang menunjukkan hasil trigliserida paling baik: HPPKN. Hasil analisis rerata kadar asam urat, kelompok yang menunjukkan hasil paling baik adalah HPPPIB dan HPKGN.

Penelitian menunjukkan bahwa kacang polong hijau maupun kuning mempunyai efek nefroprotektif. ${ }^{13} \mathrm{Hal}$ ini disebabkan karena hidrolisat protein kacang polong mempunyai efek antioksidan dan inhibisi terhadap angiotensin I-converting enzyme (ACE). Inhibisi enzim ACE mengakibatkan penurunan tekanan darah dan vasodilatasi sehingga terjadi peningkatan aliran darah dan nutrisi ke ginjal meningkat sehingga fungsi ginjal membaik. Kadar asam urat serum yang tinggi terdapat pada pasien penderita PGK karena asam urat tidak diekskresikan dengan baik oleh ginjal, sehingga dengan membaiknya fungsi ekskresi ginjal akan menurunkan kadar asam urat. ${ }^{13,14}$ Mekanisme kerja protein hidrolisat kacang polong hijau yang dihidrolisis dengan enzim bromelain dalam menurunkan kadar kolesterol total serum tikus Wistar jantan adalah melalui aktivitas antioksidan, yang banyak terkandung di dalamnya. Hasil analisis berat molekul 
menggunakan SDS PAGE dari hidrolisat protein-protein kacang polong yang digunakan dalam penelitian ini, memperlihatkan banyak pita di sekitar dan di bawah $10 \mathrm{kDa} .{ }^{11}$ Hasil penelitian Stanisavljević menunjukkan bahwa protein hidrolisat kacang polong dengan berat molekul kurang dari $10 \mathrm{kDa}$ memiliki aktivitas antioksidan yang tinggi. ${ }^{15}$ Berat molekul yang kecil juga memperlihatkan keuntungan yaitu semakin kecil berat molekul suatu protein, maka protein tersebut akan semakin mudah diserap oleh tubuh. ${ }^{9}$ Kacang polong yang digunakan dalam penelitian ini telah diperiksa metabolit sekundernya, dan terbukti mengandung senyawa tanin dan fenol yang bersifat sebagai antioksidan. ${ }^{16}$ Antioksidan sangat bermanfaat dalam mencegah penurunan fungsi ginjal lebih lanjut.

Hasil penelitian Aluko dan Aukema, tikus yang diberi asupan protein hidrolisat kacang polong menunjukkan perbaikan fungsi ginjal akibat peningkatan produksi enzim COX-1. COX1 menyebabkan dilatasi pembuluh darah dan memperbaiki kemampuan ginjal dalam memfiltrasi darah dan memproduksi urine. ${ }^{17}$ Menurut Hörl, perbaikan fungsi ginjal dapat mencegah kehilangan albumin, penurunan produksi lipoprotein dan trigliserida. ${ }^{18} \mathrm{COX}-1$ banyak diekspresikan pada sel mesangial ginjal, sel endotel arteriolar, sel parietal kapsula Bowman, serta tubulus kolektivus korteks dan medulla. ${ }^{19}$

Tikus yang diberi pakan protein hidrolisat kacang polong menunjukkan perbaikan fungsi ginjal dan tidak menunjukkan efek samping yang tidak diinginkan. ${ }^{20,21}$ Menurut penelitian Hellendorm, konsumsi kacang polong pada manusia menyebabkan peningkatan ekskresi asam empedu, sehingga berefek menurunkan hiperkolesterolemia. ${ }^{22}$

Hidrolisat protein kacang diberikan sejak awal penelitian yaitu sejak hari ke-1 hingga hari ke-30, dimaksudkan untuk mengetahui efek protektifnya terhadap ginjal yang dirusak oleh CP. Hidrolisat protein kacang polong diketahui memiliki banyak khasiat, seperti antimikrobial, penurunan tekanan darah (efek ACE inhibitor), penurunan kadar kolesterol, antitrombotik, aktivitas antioksidan, peningkatan penyerapan atau bioavailabilitas mineral, imunomodulator, dan aktivitas opioid. ${ }^{13}$ Famili Fabaceae, yang dikenal sebagai biji keluarga legume bermanfaat dalam pencegahan hiperkolesterolemia dan hipertensi. ${ }^{14}$ Manfaat Legume dapat berkurang akibat pengaruh beberapa faktor seperti degradasi bioaktif peptida aktif saat dicerna, atau tidak diabsorpsi, atau tidak mencapai jaringan target. ${ }^{13}$ Dibutuhkan penelitian lebih lanjut untuk mengetahui mekanisme dan komponen aktif yang terdapat pada legume.

Pea protein isolate (PPI) merupakan bentuk protein yang dimurnikan dan sangat banyak diproduksi serta diteliti di Kanada. PPI meningkatkan reseptor LDL sehingga menyebabkan hipolipidemia. Mekanisme kerja efek penurun lipid dari protein kacang polong masih kontroversial dan belum sepenuhnya dipahami. Hidrolisat protein kacang tampaknya 


\section{Research Article}

memengaruhi homeostasis lipid di tingkat seluler dengan dua cara; yang pertama dengan cara mengaktifkan gen yang terlibat dalam pengambilan kolesterol hepatik dan yang kedua, dengan cara meregulasi gen yang menyintesis asam lemak. ${ }^{23}$ Peran protease ternyata cukup besar dalam menurunkan kadar lemak darah, karena dapat mengekspresikan reseptor LDL sehingga meningkatkan uptake dan degradasi dari LDL. ${ }^{24}$

Hidrolisat protein kacang polong memiliki sifat bioaktif yang dapat memperbaiki gejala negatif akibat kerusakan ginjal. HPPHB adalah kelompok yang menunjukkan penurunan parameter fungsi ginjal, kadar ureum dan kreatinin paling besar, ${ }^{11}$ dan dalam penelitian ini menunjukkan hasil pemeriksaan HDL paling baik. Mengingat tujuan penelitian ini adalah menemukan sumber kacang polong yang berasal asli dari Indonesia, maka HPPHB merupakan hidrolisat protein yg layak diteliti lebih lanjut karena cukup menjanjikan sebagai terapi penyakit gangguan ginjal di masa mendatang.

\section{Simpulan}

Hidrolisat protein kacang polong asal Indonesia dan Kanada menunjukkan efek hipolipidemik yang baik terhadap Kolesterol Total, Low Density Lipoprotein (LDL), High Density Lipoprotein (HDL), Trigliserida; dan Asam Urat tikus Wistar yang diinduksi CP.

\section{Ucapan Terima Kasih}

Kami berterima kasih atas dukungan dana dari Direktorat Jenderal Penguatan Penelitian dan Pengembangan, Kementerian Riset, Teknologi, dan Pendidikan Tinggi Indonesia untuk hibah penelitian 2018, SP DIPA-042.06.1.401516 / 2018.

\section{Daftar Pustaka}

1. Kidney Disease: Improving Global Outcomes (KDIGO) CKD Work Group.KDIGO 2012 Clinical Practice Guideline for the Evaluation and Management of Chronic Kidney Disease. Kidney Int Suppl. 2013;3(1):136-50

2. Jha V, Garcia-Garcia G, Iseki K, Li Z, Naicker S, Plattner B, et al. Chronickidney disease: Global dimension and perspectives. Lancet. 2013;382: 260-72.

3. Levey AS, Coresh J. Chronic kidney disease. Lancet. 2012; 379(9811):165-80.

4. Dugbartey GJ, Peppone LJ, de Graaf IA. An integrative view of cisplatin-induced renal and cardiac toxicities: Molecular mechanisms, current treatment challenges and potential protective measures.Toxicology. 2016;371:58-66.

5. Vaziri ND. Molecular mechanisms of lipid disorders in nephrotic syndrome. Kidney Int 2003;63:1964-76. [Cited 2017 December, 18], Available from: https://www.ncbi.nlm.nih.gov/books/NBK305899/

6. Tsimihodimos V. Dyslipidemia Associated with Chronic Kidney Disease. Open Cardiovasc Med J [Internet]. 2011; 5: 41-48. [Cited 2018 October, 31], Available from: https://www.ncbi.nlm.nih.gov/pmc/articles/PMC3106357/

7. Prasad Sah OS, Yu XQ. Association Between Hyperuricemia and Chronic Kidney Disease: A Review. Nephrourol Mon. 2015;7(3): e27233.[Cited January $3^{\text {th }}$ 2019] Available at https://www.ncbi.nlm.nih.gov/pmc/articles/PMC4537598/ 


\section{Research Article}

8. Krefting J. The Appeal of Pea Protein [Internet]. Journal of Renal Nutrition. 2017. [Cited: 2017 December, 18], Available from: https://www.jrnjournal.org/article/S1051-2276(17)30151-6/fulltext.

9. Hoskins I. Pea protein may prevent kidney disease [Internet]. 2017. [Cited:2017 December, 19], Available from: http://www.cabi.org/nutritions/news/19303.

10. Hidayat M. Preparation and Examination of Hydrolysate Protein of Green Peas by bromelain for Improvement Kidney Function. Minist Justice Hum Rights Dir Gen Intellect Prop Republik of Indonesia Copyright. EC00201810615, 2018.

11. Hidayat M. Hidrolisat protein dari Kacang Polong Hijau (Pisum sativum.L) untuk Penyakit Ginjal Kronis. Monograf. Penerbit Alfabeta. Bandung. 2018. p 110.

12. Giknis MLA CC. Clinical Laboratory Parameters for Crl: WI (Han). Montreal: Charles River Accelerating drug development; 2008. p 9

13. Li H \& Aluko RE. Identification and inhibitory properties of multifunctional peptides from pea protein hydrolysate. J Agric Food Chem.2010; 58(21):11471-6.

14. Aluko RE. Antihypertensive Peptides from Food Proteins. Ann Rev Food Sci Tech.2015; 6(1): 235-62.

15. Jovanović Ž, Stanisavljević N, Mikić A, Radović S, Maksimović V. The expression of drought responsive element binding protein (DREB2A) related gene from pea (Pisum sativum L.) as affected by water stress. Aust J Crop Sci. 2013; 7(10):1590-6.

16. Wang X, Warkentin TD, Briggs CJ, Oomah BD, Campbell CG, Woods S. Total phenolics and condensed tannins in field pea (Pisum sativum L.) and grass pea (Lathyrus sativus L .). Euphytica. 1998;101:97-102.

17. Aluko RE and Aukema HM. Effects of a novel pea protein hydrolysate on hypertension and chronic kidney disease. Oral paper presented at the American Chemical Society conference, Salt Lake City, Utah, March 22-26, 2009.

18. Hörl W. Nonsteroidal Anti-Inflammatory Drugs and the Kidney.Pharmaceuticals.2010; 3(7): 2291-321.

19. Mune M, Otani H, Yukawa S. Effects of antioxidants on kidney disease. Mech Ageing Dev. 2002; 123(8):10416.

20. Kim G. Renal effects of prostaglandins and cyclooxygenase-2 inhibitors. Electrolyte Blood Press. 2008;6(1):3541.

22. Meireles CL, Price SR, Pereira AML, Carvalhaes JTA, Mitch WE. Nutrition and Chronic Renal Failure in Rats What Is an Optimal Dietary Protein? J Am Soc Nephrol [Internet]. 1999;10(11):2367-73.

23. Hellendoorn EW. Beneficial physiological activity of leguminous seeds. Qualitas Plantarum. 1979;29(1-2):22744. Plant Foods for Human Nutrition. ISSN 0921-9668 (Print) 1573-9104 (Online)

24. Rigamonti E, Parolini C, Marchesi M, Diani E, Brambilla S, Sirtori CR, et al. Hypolipidemic effect of dietary pea proteins: Impact on genes regulating hepatic lipid metabolism. 2010;54(1):S24-30.

24. Udenigwe $\mathrm{CC} \&$ Aluko RE. Food protein-derived bioactive peptides: Production, processing, and potential health benefits. J Food Sci. 2012;71(1):R11-24. 